Jurnal Mahasiswa BK An-Nur : Berbeda, Bermakna, Mulia

Volume 4 Nomor 1 Tahun 2018

Tersedia Online: https://ojs.uniska-bjm.ac.id/index.php/AN-NUR

ISSN. 2460-9722

\title{
PENGARUH LAYANAN BIMBINGAN KELOMPOK DALAM MENINGKATKAN MINAT BELAJAR SISWA KELAS IX DI MTs NURUL FALAH JUAI KABUPATEN BALANGAN
}

\author{
Lailatul Husna, Farial, Eka Sri Handayani \\ Universitas Islam Kalimantan Muhammad Arsyad Al-Banjari \\ lailatulhusna1995@gmail.com
}

\begin{abstract}
ABSTRAK
Latar belakang dan tujuan utama yang mendasari penelitian ini adalah untuk mengetahui apakah minta belajar siswa meningkat setelah diberikan layanan bimbingan kelompok dan bagaimana pengaruh layanan bimbingan kelompok dalam meningkatkan minat belajar siswa kelas IX di MTs. Nurul Falah Juai Kabupaten Balangan. Jenis penelitian ini adalah kuantitatif. Populasi dalam penelitian ini adalah siswa MTs. Nurul Falah Juai Kabupaten Balangan. Sampel penelitian ini diambil dengan teknik purpusive sampling sehingga diperoleh jumlah sempel dalam penelitian ini sebanyak 10 siswa. Variabel yang digunakan yatiu layanan bimbingan kelompok sebagai variabel bebas, dan problema rendahnya minat belajar siswa sebagai variable. Uji validitas instrument menggunakan korelasi producct moment, dan di lanjutkan uji reabilitas dengan menggunkan rumus Alpha. Hasil penelitian menunjukkan bahwa adanya pengaruh layanan bimbingan kelompok dalam meningkatkan minat belajar siswa kelas IX MTs. Nurul Falah Juai Kabupaten Balangan dengan tingkat minat belajar siswa sebelum diberikan layanan bimbingan kelompok rata-rata berada pada kategori sedang dengan persentase $56 \%$, dan setelah diberikan layanan bimbingan kelompok minat belajar siswa masuk dalam kategori tinggi dengan persentase $78 \%$. Kesimpulan penelitian ini menunjukkan bahwa adanya pengaruh layanan bimbingan kelompok dalam meningkatkan minat belajar siswa kelas IX di MTs. Nurul Falah Juai Kabupaten Balangan. Saran bagi guru/wali kelas hendaknya memperhatikan dan memantau minat belajar siswa yang rendah. Bagi konselor sebagai masukan dan bahan pertimbangan sehingga pelaksanaan layanan bimbingan kelompok dapat selalu berjalan. Untuk kampus menambah bahan kepustakaan dan menambah bahan bagi mahasiswa UNISKA yang akan kelapangan sebagai konselor.
\end{abstract}

Kata kunci: Layanan Bimbingan Kelompok, Minat Belajar

\begin{abstract}
The underlying background of this study is The main objective of this study was to find out whether to ask for increased student learning after being given group counseling services and how the influence of group counseling services in improving students' interest in class IX in MTs. Nurul Falah Juai Regency Balangan. The sample of this research is taken by purpusive sampling technique so that the number of sempel in this research is 10 students. The variables used are group counseling services as independent variables, which are denoted by $(X)$ and and the problem of low student interest as a dependent variable denoted by $(Y)$. Instrument validity test using producct moment correlation, and continue the reliability test using Alpha formula. The results showed that the influence of group guidance services in improving students' interest in class IX MTs. Nurul Falah Juai Regency Balangan. The level of students 'interest in learning before being given the guidance service of the average group of students' interest level is in the moderate category with the percentage of 56\%, and after being given guidance service the student interest group enter into the high category with the percentage $78 \%$. The conclusions of this study indicate that the influence of group guidance services in improving student interest in class IX in MTs. Nurul Falah Juai Regency Balangan. Advice for teachers / homeroom teachers should pay attention and monitor students' low interest in learning. For the counselor as input and consideration materials so that the implementation of group guidance services can always run. To campus add library materials and add materials for UNISKA students who will spaciousness as a counselor.
\end{abstract}

Keywords: Group Guidance Services, Interest in Learning

Dipublikasikan Oleh :

UPT Publikasi dan Pengelolaan Jurnal

Universitas Islam Kalimantan Muhammad Arsyad Al-Banjari Banjarmasin 
Lailatul Husna, Farial, Eka Sri Handayani

Jurnal Mahasiswa BK An-Nur : Berbeda, Bermakna, Mulia

Volume 4 Nomor 1 Tahun 2018

Tersedia Online: https://ojs.uniska-bjm.ac.id/index.php/AN-NUR

ISSN. 2460-9722

\section{PENDAHULUAN}

Keseluruhan proses pendidikan di sekolah, kegiatan belajar merupakan kegiatan yang paling pokok. Ini berarti berhasil tidaknya pencapaian tujuan pendidikan banyak bergantung kepada bagaimana proses belajar yang dialami oleh murid sebagai peserta didik. Apabila siswa tidak memiliki minat dalam belajar maka hasil belajar yang diperoleh tidak akan bisa optimal. Belajar merupakan proses manusia untuk mencapai berbagai macam kompetensi, keterampilan, dan sikap. elajar mempunyai keuntungan, baik bagi individu maupun bagi masyarakat. Dengan belajar membawa perubahan bagi siswa.

Slameto (2013: 180) minat adalah sutau rasa lebih suka dan rasa ketertarikan pada suatu hal atau aktivitas, tanpa ada yang menyuruh. Minat pada dasarnya adalah penerimaan akan suatu hubungan antara diri sendiri dengan sesutau dari luar diri. Semakin kuat atau semakin dekat hubungan tersebut, semakin besar minat."

Berdasarkan observasi dan wawancara dengan guru pembimbing di MTs. Nurul Falah Juai kabupaten Balangan diperoleh data bahwa siswa kelas IX MTs. Nurul Falah Juai Kabupaten Balangan mempunyai masalah minat belajar yang rendah, hal ini di sebabkan oleh beberapa faktor adalah belajar tidak teratur, tidak disiplin dalam belajar, tidak tahu bagaimana cara berkonsentrasi dalam belajar, mengabaikan masalah pengaturan waktu dalam belajar, kurang menariknya cara belajar yang harus siswa hadapi setiap hari, tidak tertarik pada pelajaran tersebut dan kurang semangat.

Berkaitan dengan permasalahan yang dihadapi siswa mengenai rendahnya minat belajar di sekolah maka perlu dilakukan peningkatan minat belajar siswa dengan menggunakan kegiatan layanan bimbingan kelompok. Bimbingan kelompok merupakan lingkungan kondusif yang memberikan kesempatan bagi anggotanya untuk menambah penerimaan diri dan orang lain, memberikan ide, perasaan, dukungan bantuan alternatif pemecahan masalah mengambil keputusan yang tepat, dapat berlatih tentang perilaku baru dan bertanggung jawab atas pilihan yang ditentukannya sendiri. Suasana ini dapat menumbuhkan perasaan berarti bagi anggota yang selanjutnya dapat meningkatkan minat belajar siswa.

Menurut Romlah (dalam Lasitosari, 2007), menyebutkan bahwa bimbingan kelompok adalah suatu teknik bimbingan yang berusaha membantu individu agar dapat mencapai perkembangannya secara optimal sesuai dengan kemampuan, bakat, minat serta nilai-nilai yang dianutnya dan dilaksanakan dalam situasi kelompok.

Dipublikasikan Oleh :

UPT Publikasi dan Pengelolaan Jurnal

Universitas Islam Kalimantan Muhammad Arsyad Al-Banjari Banjarmasin
"Menurut Sukardi (dalam Syahrul, 2015: 48) "Layanan bimbingan kelompok adalah layanan yang memungkinkan sejumlah siswa secara bersama-sama memperoleh bahan dari nara sumber tertentu (terutama guru pembimbing atau konselor) yang berguna untuk menunjang kehidupan sehari-hari baik individu sebagai pelajar, anggota keluarga, dan masyarakat serta untuk mempertimbangkan dalam pengambilan keputusan".

Upaya dalam meningkatkan dan mengembangkan minat belajar siswa dapat dilakukan dengan kegiatan layanan bimbingan kelompok, untuk menumbuhkan minat belajar siswa konselordiharapkan mampu menumbuhkan ketertarikan dalam belajar. Dengan bimbingan kelompok diharapkan siswa dapat saling bertukar pikiran dan mengemukakan pendapat yang dimilikinya.

\section{METODE}

Metode penelitian yang digunakan dalam penelitian ini adalah kuantitatif. Karena jenis penelitian yang akan dilakukan adalah penelitian korelasi sebab dalam penelitian ini dimaksudkan untuk melihat atau mengetahui pengaruh layanan bimbingan kelompok dalam meningkatkan minat belajar siswa. Dengan data yang dapat diuraikan dan dihitung secara langsung karen berupa angka. Penelitian dapat mebandingkan kecenderungan perubahan skor sebelum dan sesudah pemberian perlakuan melalui skala tingkat minat belajar.

Yang dilakasanakan dalam tiga tahap, yaitu: 1). Melaksanakan pre test untuk mengetahui kondisi awal responden sebelum diberikan perlakuan, 2). Memberkan perlakuan berupa layanan bimbingan kelompok, 3). Melakukan post tetsuntuk mengetahui keadaan variable terikat sesudah diberikan layanan bimbingan kelompok.

Populasi dalam penelitian ini adalah seluruh kelas IX yang terdiri dari 2 kelas yaitu kelas IX A dan IX B dengan jumlah siswa keseluruhan 53 orang siswa. Kelompok layanan bimbigan kelompok beranggotakan 10 orang siswa kelas IX A yang mengalami minat belajar rendah. Siswa yang menjadi subjek penelitian ditetapkan berdasarkan hasil pengisian angket pre test tingkat minat belajar, yaitu siswa yang mengalami persentase tingkat minat belajar rendah. Kemudian bimbingan kelompok dilaksanakan sebanyak 4 kali pertemuan dengan membahas topic tugas.

Alat pengumpulan data yang digunakan adalah angket. Angket yang digunakan memiliki 5 alternatif jawaban yaitu, sangat sesuai, sesuai, kurang sesuai, tidak sesuai, sangat tidak sesuai. Instrument langsung diberikan kepada sampel yang mengikuti 
Lailatul Husna, Farial, Eka Sri Handayani Jurnal Mahasiswa BK An-Nur : Berbeda, Bermakna, Mulia

Volume 4 Nomor 1 Tahun 2018

Tersedia Online: https://ojs.uniska-bjm.ac.id/index.php/AN-NUR

ISSN. 2460-9722

layanan bimbingan kelompok pada sebelum (pre test) dan setelah (pos tetst) diberikan layanan bimbingan kelompok.

Uji validitas yang digunakan dalam penelitian ini adalah validitas konstruk (Construct Validity). Menurut Fraenkel (dalam Siregar 2010: 163) validitas konstruk merupakan yang terluas cakupannya dibanding dengan validitas lainnya, karena melibatkan banyak prosedur termasuk validitas isi dan validitas kriteria. Uji Validitas digunakan rumus korelasiProduct Moment sebagai berikut:

Rumus Korelasional Product Moment :

Rumus :

$$
r_{x y}=\frac{N \cdot \sum X Y-\left(\sum X\right)\left(\sum Y\right.}{\sqrt{N \cdot \sum X^{2}}-\left(\sum X^{2}\right) N \sum Y\left(\sum Y^{2}\right)}
$$

Keterangan :

Rxy = Koefisien korelasi

$\mathrm{N}=$ Jumlah responden

$\mathrm{X}=$ Skor Item $\mathrm{X}$

$\mathrm{Y}=$ Skor Item $\mathrm{Y}$

Rumus yang digunakan untuk mencari nilai reabilitas instrument adalah alpha.

Keterangan:

$$
r_{1.1}=\left(\frac{k}{k-1}\right)\left(1-\frac{r_{1.1}}{\sigma^{2} t}\right)
$$

$\mathrm{R}_{1.1 \text { = reabilitas instrument }}$

$\mathrm{K}=$ banyaknya butir pertanyaan atau banyaknya soal

$\mathrm{R}_{1.1=\text { jumlah varian butir }}$

$\sigma^{2} t=$ vairans total

Tehnik analisi data dipergunakan untuk menjawab permasalahan penelitian yang telah dirumuskan. Data yang terkumpul dianalisis dengan menggunakan analisis Peired Sampel T-test. Paired
T-test atau yang lebih dikenal Pre-Post Design adalah sebuah ter hepotesis non parametik statistik untuk menilai apakah dua sampel yaitu pretest dan postest. Penggunaan Paired Sampel T-test dengan menggunakan program sofware statistik untuk mengukur maen dua buah kelompok yang independen sama lain. Dengan rumus sebagai berikut:

$$
t=\frac{d}{S D_{-} d / \sqrt{N}}
$$

Keterangan :

$$
\begin{aligned}
& \mathrm{t}=\text { Nilai uji-t } \\
& \mathrm{d}=\text { Rata-rata deviasi / masing-masing subjek } \\
& \mathrm{SD} \text { _d = Standar Deviasi dari deviiasi }
\end{aligned}
$$
/selisih masing-masing subjek

Apabila t-hitung <t-tabel, maka (Ha diterima, Ho ditolak), sebaliknya jika t-hitung >t-tabel, maka(Ha ditolak, Ho diterima) dengan taraf signifikasi $1 \%$ atau a (0.01). untuk mempermudah perhitungan maka peneliti menggunakan SPSS 16.0 for Windows.

\section{HASIL DAN PEMBAHASAN HASIL}

Penentuan populasi dan sampel penelitian dilakukan dengan cara pre test dengan Probabillty sampling yang dipakai adalah dengan random sampling, dari hasil pre test dan kemudian dianalisis terdapat 10 orang siswa kelas IX yang memiliki minat

\begin{tabular}{|c|c|c|c|c|c|c|}
\hline \multirow{2}{*}{ No } & \multirow{2}{*}{$\begin{array}{l}\text { Resp } \\
\text { onde } \\
\text { n }\end{array}$} & \multicolumn{2}{|l|}{ Pre Test } & \multicolumn{2}{|l|}{ Pos Tes } & \multirow{2}{*}{$\begin{array}{l}\text { Peningk } \\
\text { atan }\end{array}$} \\
\hline & & Persentase & Kategori & Persentse & Kategori & \\
\hline 1 & R3 & $50 \%$ & Rendah & $82 \%$ & Tinggi & $32 \%$ \\
\hline 2 & $\mathrm{R} 4$ & $39 \%$ & Rendah & $80 \%$ & Tinggi & $41 \%$ \\
\hline 3 & R7 & $47 \%$ & Rendah & $80 \%$ & Tinggi & $33 \%$ \\
\hline 4 & R10 & $50 \%$ & Rendah & $86 \%$ & Sangat Tinggi & $36 \%$ \\
\hline 5 & R14 & $42 \%$ & Rendah & $75 \%$ & Tinggi & $33 \%$ \\
\hline 6 & R17 & $41 \%$ & Rendah & $85 \%$ & Sangat Tinggi & $44 \%$ \\
\hline 7 & $\mathrm{R} 18$ & $43 \%$ & Rendah & $86 \%$ & Sangat Tinggi & $43 \%$ \\
\hline 8 & R19 & $44 \%$ & Rendah & $87 \%$ & Sangat Tinggi & $43 \%$ \\
\hline 9 & R24 & $35 \%$ & Sangat Rendah & $80 \%$ & Tinggi & $46 \%$ \\
\hline 10 & R26 & $42 \%$ & Rendah & $88 \%$ & SangatTinggi & $45 \%$ \\
\hline
\end{tabular}
belajar rendah dengan 6 orang siswa perempuan dan 4 orang siswa laki-laki. Siswa tersebut adalah AH, FWS, MA, N, R, RNA, SHNA, SI, S, dan YES.

Hasil Pre Test dan Pos Test

Minat Belajar Siswa Sampel Penelitian Secara Keseluruhan

Hasil persentase 10 siswa sempel penlitian dapat disajikan dalam bentuk grafik untuk melihat tingkat minat belajar siswa hasil persentase, yaitu sebagai berikut:

Dipublikasikan Oleh :

UPT Publikasi dan Pengelolaan Jurnal

Universitas Islam Kalimantan Muhammad Arsyad Al-Banjari Banjarmasin 


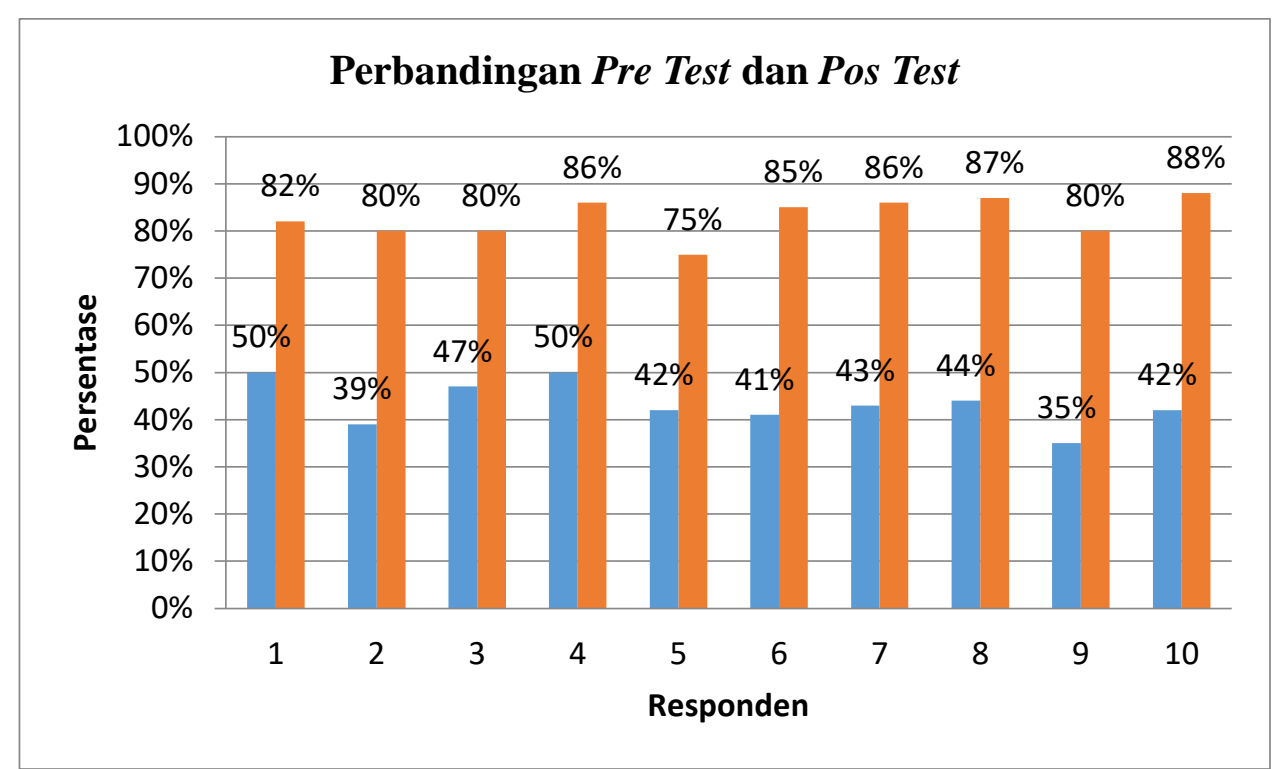

Gambar4.4 Grafik Perbandingan Hasil Persentase Pre Test dan Pos Test

\section{PEMBAHASAN}

Dilihat dari hasil perhitungan analisis deskriptif dapat diketahui bahwa sebelum diberikan layanan bimbingan kelompok minat belajar dari 10 orang siswa sampel penelitian terdapat 1 orang siswa yang memiliki minat belajar sangat rendah dengan persentase $35 \%$ dan 9 orang siswa memiliki minat belajar rendah dengan persentase berkisar dari 39\% sampai dengan 50\%. Hal ini menunjukkan bahwa kebanyakan siswa di kelas IX memiliki tingkat minat belajar yang belum baik dan secara persentase dalam kategori rendah.

Setelah diberikan perlakuan berupa layanan bimbingan kelompok minat berlajar siswa meningkat. Dapat dilihat perbedaan perubahannya dari kreteria rendah dengan ratarata persentase $43 \%$ menjadi tinggi dengan rata-rata persentase $83 \%$, yang artinya mengalami peningkatan sebesar $40 \%$. Jadi minat belajar siswa dapat ditingkatkan melalui layanan bimbingan kelompok.

Terlihat pula pada indikator permasalahan minat belajar siswa yang mengalami peningakatan dari sebelum dan sesudah diberikan perlakuan, persentase ratarata idikator pada saat sebelum diberikan perlakuan berupa layanan bimbingan kelompok yaitu $40 \%$ masuk dalam kategori rendah, dan sesudah diberikan perlakuan berupa layanan bimbingan kelompok rata-rata perentase indikator meningkat menjadi $78 \%$ masuk dalam kategori tinggi. Jadi peningkatan pada indikator permasalahan minat belajar yaitu sebesar 38\% yang berarti kseluruhan indikator mengalami kenaikan yang cukup signifikan.

Layanan bimbingan kelompok berpengaruh dalam meningkatkan minat belajar siswa kelas IX di MTs. Nurul Falah Juai, hal ini dapat dilihat dari hasil uji hepotesis T-test menunjukkan bahwa t-hitung < t-tabel $(-17,618$ $<2,8821$ ) maka hepotesis awal (Ho ditolak) dan hepotesis kerja (Ha diterima).

\section{PENUTUP}

Minat belajar siswa kelas IX Di MTs. Nurul Falah Juai Kabupaten Balangan sebelum diberikan layanan bimbingan kelompok berada pada kategori rendah yaitu dengan rata-raata persentase $43 \%$, sesudah diberikan layanan bimbingan kelompok minat belajar siswa beradapa pada kategori tinggi yaitu denggan rata-rataa persentase $83 \%$. Jadi, minat belajar siswa dapat ditingkatkan melalui layanan bimbingan kelompok karena mengalami peningkatan yang cukup signifikan yaitu dengan perbndingan $40 \%$ sebelum dan sesudah diberikan layanan bimbingan kelompok. Layanan bimbingan kelompok berpengaruh dalam meningkatkan minat belajar siswa kelas IX di MTs. Nurul Falah Juai, hal ini dapat dilihat dari hasil uji hepotesis T-test menunjukkan bahwa t-hitung $<$ t-tabel $(-17,618$ $<2,8821$ ) maka hepotesis awal (Ho ditolak) dan hepotesis kerja (Ha diterima).

\section{REFERINSI}

Dipublikasikan Oleh :

UPT Publikasi dan Pengelolaan Jurnal

Universitas Islam Kalimantan Muhammad Arsyad Al-Banjari Banjarmasin 
Lailatul Husna, Farial, Eka Sri Handayani Jurnal Mahasiswa BK An-Nur : Berbeda, Bermakna, Mulia Volume 4 Nomor 1 Tahun 2018

Tersedia Online: https://ojs.uniska-bjm.ac.id/index.php/AN-NUR

ISSN. 2460-9722

Angreani, Ditta dkk. 2015. Peningkatan Minat Belajar dengan Menggunakan Layanan Bimbingan Kelompok Pada Siswa SMP. Jurnal Bimbingan dan Konseling Universitas Lampung.

Al-Maqassary Ardi. 2014. Pengertian Bimbingan Kelompok.

Fauziah Nur. 2010. Minat Belajar Pendidikan Agama Islam Pada Siswa Kelas VIII SMP AL-Mubarak Pondok Aren Tanggerang Selatan. Skripsi Unirsitas Islam Negeri Syarif Hidayatullah.

Hafizah, Aulia. 2016. Layanan Bimbingan Kelompok Untuk Menurangi Efek Negatif Penggunaan Handphone pada Siswa Kelas X SMA KORPRI Banjarmasin. Skripsi Universitas Islam Kalimantan Muhammad Arsyad AlBanjary (UNISKA MAB)

Musfiqun. 2012. Metode Penelitian pendidikan. Jakarta: PT. Prestasi Pustakanya

Masturi, Sutarti. 2013. Meningkatkan Kemampuan Beradaptasi Melalui Layanan Bimbingan Kelompok Siswa Kelas X SMA 2 Kudus. Jurnal Staf Pengajar Fakultas Keguruan dan Ilmu Pendidikan UMK, Volume 6, Nomor 2. Hal 41

Mukhlis, Wahyudi 2015. Peranan Bimbingan Kelompok Untuk Meningkatkan Minat Belajar Siswa di SMP Negeri 6
Kandangan. Skripsi Universitas Islam Kalimantan Muhammad Arsyad AlBanjary (UNISKA MAB)

Nurcholifa,Siti. 2014. Pengaruh Layanan Bimbingan Kelompok Terhadap Minat Belajar Siswa Kelas VII Madrasah Tsanawiyah Banu Hasyim Janti Waru Sidoarjo. Skripsi Universitas Negeri Sunan Ampel Suarabaya

Syahrul M. 2015.Pengaruh Layanan Bimbingan Kelompok Terhadap Peningkatan Penyesuian Diri Siswa". Journal of EST, Volume 1, Nomor 1,. hal $46-60$

Sugiyono. 2010. Metode Penelitian Pendidikan Pendekatan Kuantitatif,Kualitatif, dan $R \& D$. Bandung: Alfabeta.

Sucipto dkk, 2013. Meningkatkan Kemampuan Beradaptasi Melali Layanan Bimbingan Kelompok Siswa Kelas X MAN 2 Kudus. Jurnal Staf Pengajar Fakultas Keguruan dan Ilmu Pendidikan UMK. Volume 6, Nomor 2.

Zulfah Nur Rosyida, 2016. Pengaruh Layanan Bimbingan Kelompok Dengan Teknik Role Playing Untuk Meningkatkan Minat Belajar Matematika Pada Siswa Kelas V Di SD Negeri Manggungan Kabupaten Banyumas. Skripsi Universitas Negeri Semarang

Dipublikasikan Oleh :

UPT Publikasi dan Pengelolaan Jurnal

Universitas Islam Kalimantan Muhammad Arsyad Al-Banjari Banjarmasin 